\title{
Antibiotic Resistance of Stenotrophomonas maltophilia Strains Isolated from Horses
}

\author{
Uçkun Sait UÇAN ${ }^{*}$, Bilal Osamah MOHAMMED ${ }^{1}$, Murat YİĞİT² \\ 1 Selcuk University, Veterinary Faculty, Microbiology Department, Konya, Turkey \\ ${ }^{2}$ Vocational School of Nafi \& Ümit Ceri, Program for Horse Riding \& Coaching, Daday, Kastamonu, Turkey
}

\begin{abstract}
Stenotrophomonas maltophilia is a member of gamma proteobacteria that has been frequently isolated from humans as well as from animals. One of the most outstanding feature of $S$. maltophilia is its antibacterial resistance that is basicly controlled by various pathways including intrinsic manner. By this study we aimed to evaluate the interaction of $S$. maltophilia suspected equine strains with various antibiotics in the presence of Thymoquinone in vitro. Disc diffusion technique was used for measuring interactions between the thymoquinone and others. No measurable inhibition zone for synergistic or antagonistic effect between the thymoquinone and test antibiotics was observed. However, the thymoquinone itself has an antibacterial potential.
\end{abstract}

Keywords: Antibiotic, horse, resistance, Stenotrophomonas maltophilia

\section{Atlardan İzole Edilen Stenotrophomonas maltophilia Suşlarının Antibiyotik Direnci}

\section{ÖZ}

Stenotrophomonas maltophilia gamma proteobacteria içerisinde yer alan ve hem insanlardan hem de hayvanlardan sik izole edilen bir bakteri türüdür. S. maltophilia'nin en dikkat çeken özelliklerinden birisi bakterinin intrinsik mekanizmalar da dahil olmak üzere çeşitli şekillerde geliştirdiği yüksek antibiyotik direncidir. Bu çalışma ile atlardan izole edilmiş olan $S$. maltophilia'nın timokionon ile çeşitli antibiyotiklerin beraber kullanıldıklarındaki etkilessimini ölçmek amaçlandı. Ne sinerjizm ne de antogonizm şeklinde bir etkileşim ölçülmedi. Ancak timokiononun S. maltophilia suşları üzerinde antibakteriyel etkisi tespit edildi..

Anahtar Kelimeler: Antibiyotik, at, direnç, Stenotrophomonas maltophilia

\footnotetext{
To cite this article: Uçan U.S Mohammed B.O. Yiğit M. Antibiotic Resistance of Stenotrophomonas maltophilia Strains Isolated from Horses. Kocatepe Vet J. (2019) 12(4):384-388. 


\section{GİRİŞ}

According to Bergey's manual system of bacteriological classification the genus Stenotrophomonas is a member of 11 genera that belong to the Xanthomonadaceae family which belongs to the bacterial class Gammaproteobacteria (Saddler and Bradbury 2005). Stenotrophomonas maltophilia (S. maltophilia), formerly called Pseudomonas (Xanthomonas) maltophilia, is a nonparasitic, nonfermentative, Gram-negative rod shaped bacteria found in habitats of aquatic, soil and plant environments (Denton and Kerr 1998).

The importance of the bacteria $S$. maltophilia is significantly increasing after it has been frequently isolated from humans after causing opportunistic nosocomial infections and more frequently from animals what made it also considered important in veterinary medicine (Çelikel 2012). The isolation of $S$. maltophilia from cases of lymphadenitis in goats (Johnson et al. 2003), arthritis in dogs (Muir et al. 2007) and mastitis in cows (Ohnishi et al. 2012), and also in special cases from the lower tracheal region of horses with chronic cough (Winther et al. 2010) has been reported.

The non-fermentative gram negative bacilli $S$. maltophilia are $0.5-1.5 \mu \mathrm{m}$ in length straight or curved non-capsuled motile rods that do not form spores. It is a catalase positive obligated aerobic bacterium that grows well in an optimal temperature of $35{ }^{\circ} \mathrm{C}$. It does not show growth in temperatures above $41{ }^{\circ} \mathrm{C}$ or lower than $4{ }^{\circ} \mathrm{C}$. The S-type colonies formed by this bacteria are usually pale yellowish White (Denton and Kerr 1998). Many strains of the S. maltophilia showed intrinsic resistance to a variety of wide spectrum antibiotics. This resistance was due to the permeability reduction in the outer cell wall and also by the aminoglycoside modifying enzymes. It has also been reported that resistance to quinolones, tetracycline and chloramphenicol occurs by overexpression of cryptic efflux pumps. S. maltophilia strains showed low susceptibility to erythromycin, while the susceptibility to trimethoprimsulfamethoxazole, minocycline and ticarcillin / clavulanate was the highest in most of the studies (Ohnishi et al. 2012, Sanchez 2015).

On the other hand, the use of antibiotics and antibacterial chemotherapeutics is becoming increasingly limited in both veterinary and human medicine. The reasons for this limitation are; the ability of bacteria to immediately develop and exhibit resistance after the administration of antibiotics and also the presence of side effects in most of the antibiotics. There is an urgent need for discovering new drugs or chemotherapeutic agents that induce less resistance and with lower toxicity (Halawani 2009). In this context, the potential aspect of various herbal extracts has been the subject of many studies. In Turkey there is a well-known folkloric plant with a high potential of being useful for the development of new antimicrobials. The plant Nigella sativa (N. sativa) that is produced and consumed in large quantities in Turkey demonstrated both biological and antibacterial effects. These effects are found in the core material contained inside this plant, the Thymoquinone (Halawani 2009, Uçan et al. 2018, Yimer et al. 2019). The Thymoquinone attracted the attention after showing an undeniable affectivity when it was administered along with some antibiotics. It showed a synergetic effect with some antibiotics when it is used against Staphylococcus aureus and it also showed synergetic, antagonistic and some have been reported to have an additive effect when it was used with the same antibiotics against some Gram-negative bacteria (Halawani 2009).

The resistance of $S$. maltophilia strains which has been isolated from various cases in veterinary medicine to many antibiotics by various pathways, including intrinsic mechanisms, appears to be an important potential problem in treatment processes. The aim of this study was to evaluate the interaction of $S$. maltophilia suspected equine strains with various antibiotics in the presence of thymoquinone in vitro.

\section{MATERYAL ve METOT}

Twenty Pseudomonas/Stenotrophomonas suspected equine isolates from the culture collections in the Department of Microbiology of the Faculty of Veterinary Medicine, Selçuk University were used. The biochemical identification of the isolates was accomplished by testing the following characteristics: colony morphology, growth on Mc Conkey Agar, Gram staining, motility, oxygen requirement, hemolysis on blood agar, catalase and oxidase activity, DNase, lysine decarboxylase, urease, $\mathrm{H}_{2} \mathrm{~S}$ production and the fermentation of lactose, sorbitol and mannitol. Twelve of the isolates were also identified as $S$. maltophilia using the vitek automated identification system (Vitek biomerieux, Konya Veterinary Control Institute). This was considered a confirmation of the previously obtained results from the biochemical testing.

\section{The measurement of antibiotic-thymocionone interaction}

Some of the commercially available antibiotics that are used for horses' treatment were tested in this

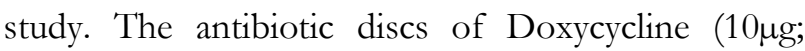

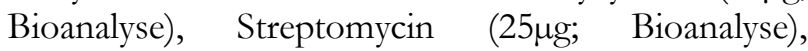
Marboflaxacin (5 $\mu$; Bioanalyse), Telithromycin (15

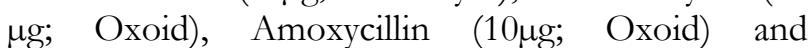
Cefaperazone (75Oxg; Oxoid) were used. Thymoquinone (Santa Cruz Biotechnology, sc215986) was diluted in Dulbecco's Modified Eagle's Medium (DMSO; Sigma-Aldrich, D8418) at a concentration of $100 \mathrm{mg} / \mathrm{mL}$ and the stock solution was stored at $+4^{\circ} \mathrm{C}$ in tubes wrapped in aluminum paper. 
Firstly, the stock solution of thymoquinone was further diluted to $60 \mathrm{mg} / \mathrm{ml}$ using sterile distilled water and $10 \mu \mathrm{l}$ of this was impregnated on sterile paper discs of $6 \mathrm{~mm}$ diameter. Twenty isolates were first tested for their susceptibility to thymoquinone on Mueller Hinton Agar (Merck, 105437). Then, as previously mentioned by Halawani (2009), the isolates were cultured on Mueller Hinton Agar (Merck, 105437) and then the antibiotic discs were placed around the disc impregnated with thymoquinone in the center. Suitable distance to the center was kept in order to allow any interaction between the thymoquinone and the antibiotics. The detection and measurement of the inhibition zones were done after 24 hours of incubation in an aerobic humid environment. The test was repeated three times.

\section{RESULTS}

According to bacterial phenotype and biochemical tests results, all strains were non motile Gram negative rods, grew under aerobic conditions, colony morphology was transparent-white, catalase, DNase, lysine decarboxylase gave positive results while $\mathrm{H}_{2} \mathrm{~S}$, urease were negative, non-reactive to sugars (lactose, sorbitol, mannitol) and only 2 isolates were alpha hemolytic while the remaining 18 strains were identified as non-hemolytic. 12 of these strains (including alpha hemolytic ones) were tested with Vitek automated system and all were identified as $S$. maltophilia (8645 vitek result code).

All 20 isolates were susceptible to timokionone and fully resistant to Cefaperazone and Amoxycillin (Table 1 and Figure 1). No measurable zone of synergistic or antagonistic effects between thymoquinone and test antibiotics was seen around any of the used discs.

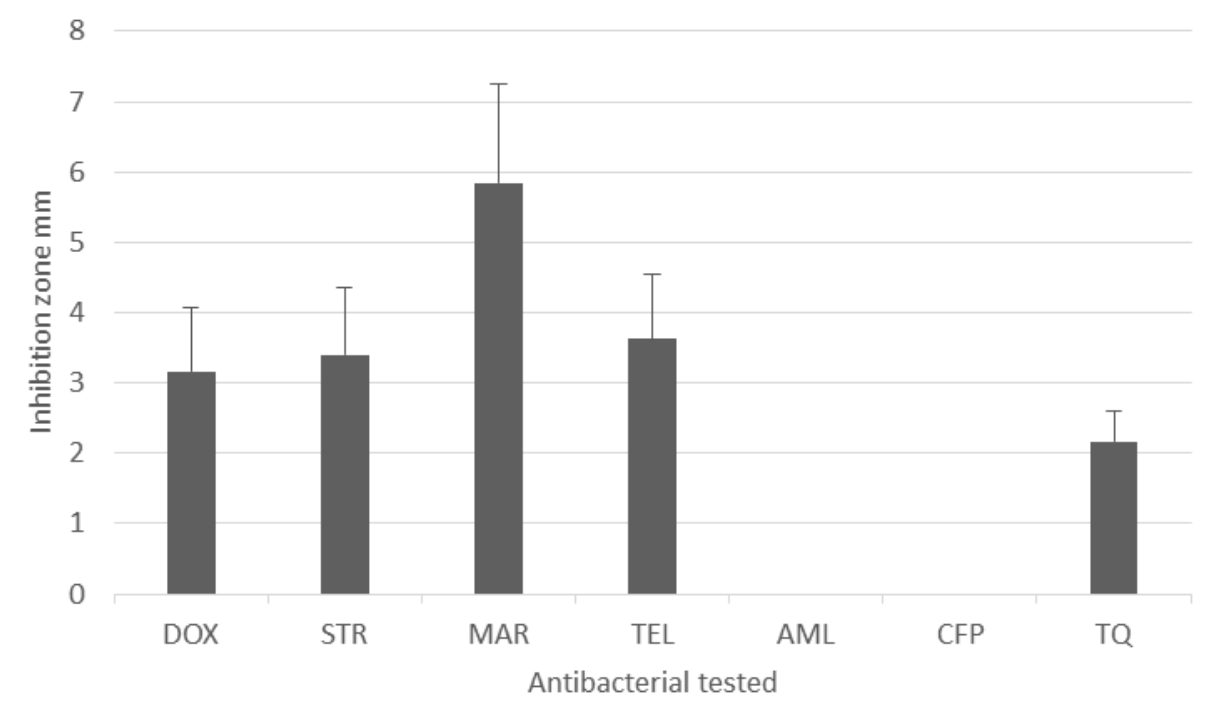

Şekil 1. S. maltophilia Suşlarının Antibakteriyel Duyarlılıkları.

Figure 1. Antibacterial Susceptibilities of S.maltophilia Strains.

DOX: Doxycycline $(10 \mu \mathrm{g})$, STR: Streptomycin $(25 \mu \mathrm{g})$, MAR: Marboflaxacin $(5 \mu \mathrm{g})$, TEL: Telithromycin $(15 \mu \mathrm{g})$, AML: Amoxycillin $(10 \mu \mathrm{g})$, CFP: Cefaperazone $(75 \mu \mathrm{g})$, TQ: Thymoquinone $(0.6 \mathrm{mg})$

Tablo 2. Antibiyotikler ve S. maltophilia Suşlarının Duyarlılıkları (Aritmetik Ortalama \pm Standart Sapma)

Table 2. Antibiotics and susceptibilities of S. maltophilia strains (mean \pm SD)

\begin{tabular}{lc}
\hline Antibacterial & Inhibition zone $(\mathbf{m m})$ \\
\hline DOX & $3.16 \pm 0.91$ \\
STR & $3.4 \pm 0.96$ \\
MAR & $5.85 \pm 1.39$ \\
TEL & $3.63 \pm 0.92$ \\
AML & 0 \\
CFP & 0 \\
TQ & $2.17 \pm 0.42$ \\
\hline
\end{tabular}

DOX: Doxycycline $(10 \mu \mathrm{g})$, STR: Streptomycin $(25 \mu \mathrm{g})$, MAR: Marboflaxacin $(5 \mu \mathrm{g})$, TEL: Telithromycin $(15 \mu \mathrm{g})$, AML: Amoxycillin $(10 \mu \mathrm{g})$, CFP: Cefaperazone $(75 \mu \mathrm{g})$, TQ: Thymoquinone $(0.6 \mathrm{mg})$ 


\section{DISCUSSION}

Despite previous consideration with over the last two decades, S. maltophilia is now accepted as a causative bacterium of serious opportunistic infections (Looney et al. 2009, Winther et al. 2010, Adegoke et al. 2017). In this study, all suspected strains of $S$. maltophilia were found non motile at $37^{\circ} \mathrm{C}$. In a previous study conducted long ago, Denton and Kerr (1998) tested the motility of $S$. maltophilia strains and reported that they considered it variable at $37{ }^{\circ} \mathrm{C}$ and also reported that the rate of motile strains was $16-85 \%$. As we can see from the results obtained from our study, the 20 isolates in this study were non motile which did not comply with the above variability in terms of motility in the previous study.

In terms of oxidase activity evaluation, Palleroni reported a typical oxidase reaction as negative for this species some ago (Palleroni 2005). In our study, when oxidase enzyme activity was evaluated, none of the isolates gave a clear positive or negative result that can be considered reliable. Denton and Kerrr in (1998)'s study did not rely on this test for the identification of the $S$. maltophilia strains and apparently believed that it was problematic. On the other hand, another study by Adegoke et al. (2017) confirmed the variability of the oxidase activity in various strains of this species.

The hemolysis was also one of the observed phenotypic properties in this study. Only 2 of the 20 strains showed some hemolytic activity. This was the second phenotypic feature that was not included in the tests to be used in $S$. maltopbilia identification proposed by Denton and Kerr (1998).

S.maltophilia is known to intrinsically be resistant to most currently available chemoterapoetics. By means of chromosomal, inducible L1 metallo-b-lactamase (MBL) and L2 b-lactamase that $S$. maltophilia possesses (Denton and Kerr 1998) an intrinsic resistance is potentially performed against most blactams, including the carbapenem class, with the exception of monobactams and b-lactames (Looney et al. 2009).

The main reason for the limitation of antibiotics use is that after the discovery of a new antibiotic there is a posibility of developing immediate resistance against it at the first time its used in addition to the side effects caused by these antibiotics. For this reason, there is a need for discovering and developing new drugs against which resistance does not develope and with no toxicity or at least with as low toxicity as possible (Halawani 2009). N. sativa, which has antimicrobial effect among its various biological effects, owes this potential to various bioactive components it contains (Yimer 2019). This feature of $N$. sativa has been known for many years. In (1991) Hanafi and Hatem reported that $N$. sativa diethyl ether extract showed a synergic effect when it is used with streptomycin, erythromycin, tobramycin, doxycycline, chloramphenicol, nalidixic acid, ampicillin, lincomycin and co-trimoxazole against Staphylococcus aureus, Pseudomonas aeruginosa and Escherichia coli in their study. A number of studies indicated that $N$. sativa has this antimicrobial effect especially with thymokinone (Hanafi and Hatem 1991, Halawani 2009, Yimer 2019). Some interesting findings showed that thymokinone has an antibacterial effect on variety of Gram negative strains including Pseudomonas aeruginosa isolates that are resistant to a large number of antibiotics at the intrinsic level, and also on Staphylococcus aureus strains regardless of their resistance to antibiotics (Halawani 20009). Researchers found a synergic effect between the thymokinone and some antibiotics such as ampicillin, cephalexin, chloramphenicol, tetracycline, gentamicin and ciprofloxacin with Staphylococcus aureus but they found a different effect in terms of synergism with Gram negative and reported that $28.9 \%$ of gram negative isolates had synergism and $23.6 \%$ had antagonistic effect. In our study the effect of thymokinone was tested on strains of a single species which is the S.maltophilia. It is important to provide different antibacterial options for bacteria with multiple resistance. There are only a limited number of antibiotics that can be used against S.maltophilia (Looney et al. 2009, Ohnishi et al. 2012, Adegoke et al. 2017). For this reason, the chemotherapeutic potential posed by thymokinone makes it a good candidate whose effect on $S$. maltophilia has to be studied whereas, in our study thymokinone did not show any kind of synergic or antagonistic interaction with any of the used antibiotics (Table 1 and Figure 1). And therefore the results in our study do not comply with the results obtained from the study of Hanafi and Hatem in 1991 on Pseudomonas aeruginosa in terms of the interaction between thymokinone and some of the used antibiotics. S.maltophilia was previously included in the same genus as Pseudomonas. It is now described under a different genus and thus the genetic differences may include the genetic coding of multiple antibiotic resistance and also in the study of Hanafi and Hatem (1991) many components along with thymokinone were administered together which could have some different effects while in our study thymokinone was used alone and that could be also responsible for the different results obtained in our study.

As a result, the antimicrobial effect of thymokinone was detected only on a limited number of equine S.maltophilia strains isolated in different periods and the antibiotics that are clinically used for horses' treatment did not show any interaction of any kind in this study. In spite of that thymokinone is still a material of a natural source that has an attractive antibacterial potential effect to be used as a single substance. 


\section{REFERENCES}

Adegoke AA, Stenström TA, Okoh AI. Stenotrophomonas maltophilia as an emerging ubiquitous pathogen: Looking beyond contemporary antibiotic therapy. Front Microbiol. 2017; 8:2276. doi: 10.3389/fmicb.2017.02276.

Celikel IU. Isolation and characterization of Stenotrophomonas maltophilia from animals and their environment. $\mathrm{PhD}$ thesis, Ankara University Health Science Institute, Ankara, 2012

Denton M, Kerr KG. Microbiological and clinical aspects of infection associated with Stenotrophomonas maltophilia. Clin Microbiol Rev. 1998; 11: 57-80.

Halawani E. Anibacterial activity of thymoquinone and thymohydroquinone of Nigella sativa L. and their interactions with some antibiotics. Adv Biol Res. 2009; 3(5-6): 148-152.

Hanafi MS, Hatem ME. Studies on the anti-microbial activity of the Nigella sativa seed (Black Cumin). J Ethnopharmacol. 1991; 34: 275-278.

Johnson EH, Al-Busaidy R, Hameed MS. An outbreak of lymphadenitis associated with Stenotrophomonas (Xanthomonas) maltophilia in Omani goats. J Vet Med. 2003; 50: 102-104.

Looney WJ, Narita M, Muhlemann K. Stenotrophomonas maltophilia: an emerging opportunist human pathogen. Lancet Infect Dis. 2009; 9: 312-323.

Muir P, Oldenhoff WE, Hudson AP, Manley PA, Schaefer SL, Markel MD, Hao Z. Detection of DNA from a range of bacterial species in the knee joints of dogs with inflammatory knee arthritis and associated degenerative anterior cruciate ligament rupture. Microb Pathog. 2007; 42: 47-55.

Ohnishi M, Sawada T, Marumo K, Harada K, Hirose K, Shimizu A, Hayashimoto M, Sato R, Uchida N, Kato H. Antimicrobial susceptibility and genetic relatedness of bovine Stenotrophomonas maltophilia isolates from a mastitis outbreak. LETT APPL MICROBIOL. 2012; 54: $572-576$.

Palleroni NJ. Genus IX. Stenotrophomonas, In: Bergey's Manual of Systematic Bacteriology, Volume Two The Proteobacteria, Part B The Gammaproteobacteria. Ed; Brenner DJ, Krieg NR, Staley JT, 2nd Ed., Springer, Switzerland. 2005; pp. 107-115.

Saddler GS, Bradburry JF. Family I. Xanthomonadaceae fam. nov In: Bergey's Manual of Systematic Bacteriology, Volume Two The Proteobacteria, Part B The Gammaproteobacteria. Ed; Brenner DJ, Krieg NR, Staley JT, 2nd Ed., Springer, Switzerland. 2005; pp. 63.

Sánchez MB. Antibiotic resistance in the opportunistic pathogen Stenotrophomonas maltophilia. Front Microbiol. 2015. 6: 658. doi: 10.3389 /fmicb.2015.00658.

Ucan US, Sayin Z, Sakmanoglu A, Uslu A. Effect of thymoquinone on proliferation of bovine peripheral blood mononuclear cells. Eurasian J Vet Sci. 2018; 34:16.

Winther L, Andersen RM, Baptiste, KE, Aalbek B, Guardabassi L. Association of Stenotrophomonas maltophilia infection with lower airway disease in the horse: A retrospective case series. Vet J. 2010; 186: 358363.

Yimer EM, Tuem KB, Karim A, Ur-Rehman N, Anwar F. Review Article Nigella sativa L. (Black Cumin): A promising natural remedy for wide range of illnesses. J Evid Based Complementary Altern Med. 2019; Article ID 1528635, 16 pages. 